\title{
Observation of nitrate coatings on atmospheric mineral dust particles
}

\author{
W. J. Li ${ }^{1,2}$ and L. Y. Shao ${ }^{1}$ \\ ${ }^{1}$ State Key Laboratory of Coal Resources and Safe Mining \& Department of Resources and Earth Science, \\ China University of Mining and Technology, Beijing, China \\ ${ }^{2}$ School of Earth and Space Exploration \& Department of Chemistry and Biochemistry, Arizona State University, \\ Tempe, AZ, USA
}

Received: 30 July 2008 - Published in Atmos. Chem. Phys. Discuss.: 14 November 2008

Revised: 6 February 2009 - Accepted: 5 March 2009 - Published: 17 March 2009

\begin{abstract}
Nitrate compounds have received much attention because of their ability to alter the hygroscopic properties and cloud condensation nuclei (CCN) activity of mineral dust particles in the atmosphere. However, very little is known about specific characteristics of ambient nitratecoated mineral particles on an individual particle scale. In this study, sample collection was conducted during brown haze and dust episodes between 24 May and 21 June 2007 in Beijing, northern China. Sizes, morphologies, and compositions of 332 mineral dust particles together with their coatings were analyzed using transmission electron microscopy (TEM) coupled with energy-dispersive X-ray (EDX) microanalyses. Structures of some mineral particles were verified using selected-area electron diffraction (SAED). TEM observation indicates that approximately $90 \%$ of the collected mineral particles are covered by visible coatings in haze samples whereas only $5 \%$ are coated in the dust sample. $92 \%$ of the analyzed mineral particles are covered with $\mathrm{Ca}-, \mathrm{Mg}-$, and Na-rich coatings, and $8 \%$ are associated with $\mathrm{K}$ - and S-rich coatings. The majority of coatings contain $\mathrm{Ca}, \mathrm{Mg}, \mathrm{O}$, and $\mathrm{N}$ with minor amounts of $\mathrm{S}$ and $\mathrm{Cl}$, suggesting that they are possibly nitrates mixed with small amounts of sulfates and chlorides. These nitrate coatings are strongly correlated with the presence of alkaline mineral components (e.g., calcite and dolomite). $\mathrm{CaSO}_{4}$ particles with diameters from 10 to 500 $\mathrm{nm}$ were also detected in the coatings including $\mathrm{Ca}\left(\mathrm{NO}_{3}\right)_{2}$ and $\mathrm{Mg}\left(\mathrm{NO}_{3}\right)_{2}$. Our results indicate that mineral particles in brown haze episodes were involved in atmospheric hetero-
\end{abstract}

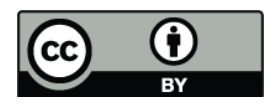

Correspondence to: L. Y. Shao (shaol@cumtb.edu.cn) geneous reactions with two or more acidic gases (e.g., $\mathrm{SO}_{2}$, $\mathrm{NO}_{2}, \mathrm{HCl}$, and $\mathrm{HNO}_{3}$ ). Mineral particles that acquire hygroscopic nitrate coatings tend to be more spherical and larger, enhancing their light scattering and CCN activity, both of which have cooling effects on the climate.

\section{Introduction}

A significant amount of mineral dust particles (1000 $3000 \mathrm{Tg}$ ) are injected into the troposphere annually (Andreae, 1995). Mineral dust particles are lifted into the atmosphere by strong surface winds and can be transported long distances (Husar et al., 2001; Fairlie et al., 2007), influencing climate, and enhancing heterogeneous chemistry of the atmosphere on regional and global scales (Ravishankara, 1997; Buseck and Posfai, 1999; Tegen et al., 2000; Xu et al., 2004; Bauer et al., 2007). Mineral dust particles scatter and absorb incoming solar radiation (Sokolik and Toon, 1996; Haywood and Boucher, 2000; Seinfeld et al., 2004) and can act as cloud condensation nuclei (CCN) (Levin et al., 1996; Yin et al., 2002). Heterogeneous chemical reactions of mineral dust with $\mathrm{HNO}_{3}$ and $\mathrm{NO}_{2}$ can influence photochemical cycles in the troposphere (Dentener et al., 1996; Jacob, 2000).

Fresh mineral dust particles in the troposphere are far more inert than chlorides, sulfates, and nitrates. When aged by soluble aerosol components, these mineral particles will have enhanced hygroscopicity and altered sizes and shapes (Krueger et al., 2003, 2004; Laskin et al., 2005b). As a result, the coated dust particles become more efficient CCN (Kelly et al., 2007). Therefore, knowledge about the soluble

Published by Copernicus Publications on behalf of the European Geosciences Union. 


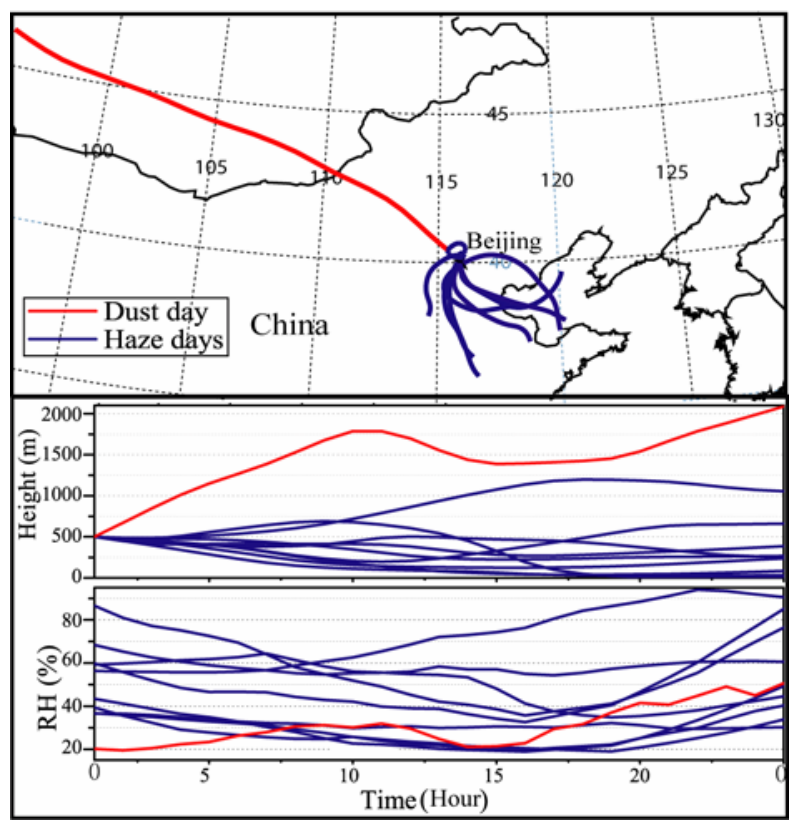

Fig. 1. Ten 24-h backward trajectories of air masses arriving at Beijing at $500 \mathrm{~m}$ and their relative humidities between 24 May and 21 June 2007. Humidities from 20 to $50 \%$ along with heights from 500 to $2200 \mathrm{~m}$ were shown in one dust air mass (red lines) from northwest of Beijing; Humidities from 20 to $92 \%$ along with heights from 20 to $1000 \mathrm{~m}$ were shown in nine haze air masses (blue lines) from southeast of Beijing.

components coated on mineral particles is important for evaluating their impact on both global and regional climates.

Laboratory experiments and modeling work suggest that climate forcing and heterogeneous atmospheric chemistry of individual mineral dust particles strongly depend on their alkaline mineral components (e.g., calcite, dolomite, and halite) (Borensen et al., 2000; Krueger et al., 2004; Kelly and Wexler, 2005). Several field studies have indicated that mineral dust particles, through heterogeneous uptake of acidic gases, acquire coatings of sulfates (Kojima et al., 2006; Sullivan et al., 2007), and/or nitrates (Zhang et al., 2000; Laskin et al., 2005a; Matsuki et al., 2005; Hwang and Ro, 2006). Although laboratory studies provided detailed information regarding nitrate coatings formed through heterogeneous reactions (Krueger et al., 2003, 2004; Laskin et al., 2005b), few studies present data on nitrate coatings detected in ambient particles.

With the rapid urbanization in China, huge amounts of emissions from cities frequently extend to regional pollution episodes (Li et al., 2007; Chan and Yao, 2008). $\mathrm{SO}_{2}$ emissions declined from 1996 to present, but $\mathrm{NO}_{\mathrm{x}}$ emissions increased by $70 \%$ (Streets et al., 2003; Zhang et al., 2007). The increase in $\mathrm{NO}_{\mathrm{x}}$ significantly affects atmospheric interactions and chemistry in Beijing (Guinot et al., 2007). In particular, the regional haze episodes that commonly occur over northern China in spring and winter include high concentrations of mineral dust particles, $\mathrm{SO}_{2}$, and $\mathrm{NO}_{2}$ (Wang et al., 2006). Mineral particles collected in the polluted hazes from northern China provide a good opportunity to study the heterogeneous reactions that occur in such ambient environments.

The goal of this study is to understand the properties of nitrate-coated mineral particles collected in regional polluted haze episodes over northern China. We used transmission electron microscopy (TEM) to observe mineral particles with visible coatings. Resolution down to fractions of a nanometer can provide detailed information on sizes, compositions, morphologies, structures, and mixing states of individual aerosol particles (Posfai et al., 1995; Buseck et al., 2000; Middlebrook et al., 2003; Johnson et al., 2005; Niemi et al., 2006). $\mathrm{Ca}\left(\mathrm{NO}_{3}\right)_{2}$ and $\mathrm{Mg}\left(\mathrm{NO}_{3}\right)_{2}$ coatings on mineral particles are studied in detail.

\section{Sampling and experiments}

\subsection{Haze and dust episodes over northern China}

Thirty-seven aerosol samples were collected in ten severe pollution brown haze episodes between 31 May and 21 June 2007 in Beijing, northern China. Temperature and relative humidity (RH) ranged from 21 to $36^{\circ} \mathrm{C}$ and 30 to $80 \%$, respectively. Visibility varied between 1 and $6 \mathrm{~km}$. Low wind speeds $\left(1-3 \mathrm{~m} \mathrm{~s}^{-1}\right)$ from a southwesterly or southerly direction dominated during the haze periods. High concentrations of $\mathrm{PM}_{10}\left(200-370 \mu \mathrm{g} \mathrm{m}^{-3}\right), \mathrm{SO}_{2}$ $\left(21-51 \mu \mathrm{g} \mathrm{m}^{-3}\right)$, and $\mathrm{NO}_{2}\left(51-88 \mu \mathrm{g} \mathrm{m}^{-3}\right)$ were monitored in the brown haze days in Beijing (http://www.bjee.org.cn/ api/index.php). In addition, four samples were collected in one dust episode on 24 May after precipitation from 21 to 23 May 2007. The dust episode was severe with a high $\mathrm{PM}_{10}$ concentration $\left(288 \mu \mathrm{g} \mathrm{m}^{-3}\right)$ and low concentrations of anthropogenic pollutants $\left(\mathrm{SO}_{2}, 9 \mu \mathrm{g} \mathrm{m}^{-3}\right.$ and $\mathrm{NO}_{2}$, $46.4 \mu \mathrm{g} \mathrm{m}^{-3}$ ). During the dust period, temperature and $\mathrm{RH}$ were $31^{\circ} \mathrm{C}$ and $21 \%$, respectively, and visibility was about $1 \mathrm{~km}$. Wind was from a westerly direction with speeds varying from 1 to $7 \mathrm{~m} \mathrm{~s}^{-1}$.

Backward trajectory analysis can determine transport paths of air masses arriving at a sampling site. The NOAA/ARL Hybrid Single-Particle Lagrangian Integrated Trajectory model (HYSPLIT) (Draxler and Rolph, 2003) was employed to calculate ten 24-h backward trajectories of air masses arriving at Beijing between 24 May to 21 June 2007 at 500 m elevation (Fig. 1). One air mass from the northwest of Beijing with low humidity passed over the desert and loess plateau of northern China, carrying a high concentration of dust particles. From southeast of Beijing, air masses with high humidity passed over the industrial Hebei, Shanxi, and Shandong provinces, bringing haze particles. The backward trajectories shown in Fig. 1 are consistent with observations 
of the meteorological parameters and mass concentrations of pollutants on the ground.

\subsection{Aerosol sampling}

The collection site $\left(39^{\circ} 59^{\prime} \mathrm{N}, 116^{\circ} 20^{\prime} \mathrm{E}\right)$ was located in the northwest of Beijing around $1 \mathrm{~km}$ from the fourth ring road of Beijing city. The height of the collection site was $60 \mathrm{~m}$ above sea level. Samplers were mounted on the top of a building located at the China University of Mining and Technology, $18 \mathrm{~m}$ above ground. The campus is surrounded by residential houses and a shopping center. The aerosol particles were deposited onto copper TEM grids coated by carbon film using a single-stage cascade impactor with a $0.5-\mathrm{mm}$ diameter jet nozzle, and an air flow rate is $1.01 \mathrm{~min}^{-1}$. The collection efficiency of the impactor is $50 \%$ for particles with an aerodynamic diameter of $0.3 \mu \mathrm{m}$ and almost $100 \%$ at $0.5 \mu \mathrm{m}$ if the density of particles is $2 \mathrm{~g} \mathrm{~cm}^{-3}$. The sampler is described in more detail by Okada and Hitzenberger (2001). Sampling time ranged from 30 to 120 s, depending on the visibility. After sampling, the TEM grids were sealed in dry plastic capsules to prevent contamination.

\subsection{Analytical methods}

Aerosol samples were analyzed using a $200 \mathrm{kV}$ Philips CM200 TEM. TEM images were used to determine particle sizes, morphologies, and mixing states. Elemental compositions were determined using energy-dispersive X-ray spectrometry (EDX). A beryllium tip holder was used to obtain elemental compositions of individual particles to decrease $\mathrm{X}$ rays sourced from the holder. Combining EDX and selectedarea electron diffraction (SAED), we were able to verify the identity of some mineral particles.

All samples were primarily observed at $\times 500$ to 800 magnification using TEM. The distributions of particles on the TEM grids were not uniform. Coarser particles were deposited near the center of each grid, and finer particles deposited on the periphery. Therefore, to ensure that the analyzed particles were representative of the collected size distribution, three to four areas were chosen from the center and periphery. Many mineral particles from haze samples show visible coatings whereas few mineral particles from dust samples show visible coatings. The primary observations allowed us to choose 20 TEM grids collected in ten brown haze episodes and one sample collected in a single dust episode in our study. Mineral particles with various sizes in the chosen samples were observed at different magnifications $(\times 2550$ to 40000$)$ using TEM. There were between 10 and 40 mineral particles measured in each haze sample. We used TEM/EDX to obtain elemental compositions of different parts of individual particles. The EDX results are semi-quantitative, especially for light elements, such as C, N, and O. Because EDX spectra were affected by carbon film and copper grids, $\mathrm{C}$ and $\mathrm{Cu}$ were not calculated in

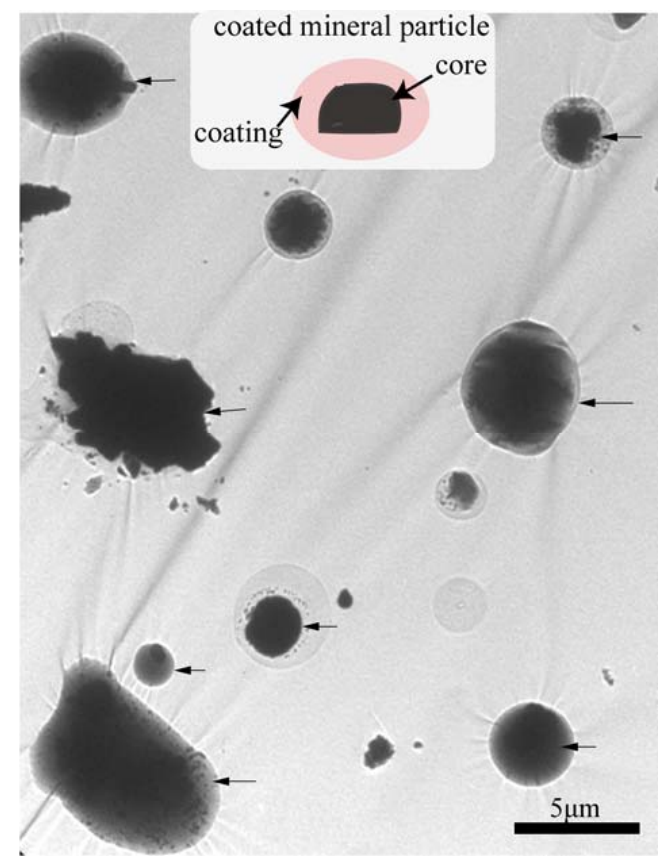

Fig. 2. TEM image of the coated mineral particles. Coated mineral particles include two parts: core and coating. Arrows indicate coated mineral particles.

our study. Therefore, inorganic components internally mixed in mineral dust particles were considered. Size of each particle was calculated using the best fitting ellipse to a particle outline, and the diameter of each particle was calculated as the arithmetic mean of the short and long axes of the ellipse (Kojima et al., 2005).

\section{Results}

\subsection{Coated mineral particles}

Mineral dust particles from the haze samples make up 1/3 (by number) of all collected aerosol particles with diameters greater than $0.1 \mu \mathrm{m}$. Other studies using bulk composition analysis indicated that mineral dust, which originated from natural soil, construction dust, and re-suspended road dust, made up about 39-67\% (by mass) in PM $_{10}$ collected during Beijing haze episodes (Sun et al., 2006). Almost all the particles collected in the dust episode are mineral dust. These dust particles were transported mainly from desert and loess soil in northwestern China (Zhang et al., 2003; Shao et al., 2008).

TEM observations indicate that approximately $90 \%$ of mineral dust particles are covered by visible coatings in haze samples, whereas only $5 \%$ are in the dust sample. We will refer to mineral dust particles associated with visible coatings as coated mineral particles (Fig. 2). Size distributions of 
Table 1. Relationships of cores and coatings of 332 mineral dust particles.

\begin{tabular}{llllllll}
\hline & $\begin{array}{l}\text { Si-rich } \\
\text { core }(\%)\end{array}$ & $\begin{array}{l}\text { Si-Al } \\
\text { core }(\%)\end{array}$ & $\begin{array}{l}\text { Ca-Mg } \\
\text { core }(\%)\end{array}$ & $\begin{array}{l}\text { Ca-rich } \\
\text { core }(\%)\end{array}$ & $\begin{array}{l}\text { Fe-rich } \\
\text { core }(\%)\end{array}$ & $\begin{array}{l}\text { Na-rich } \\
\text { core }(\%)\end{array}$ & $\begin{array}{l}\text { number of } \\
\text { particles }\end{array}$ \\
\hline Ca-rich coating & 6 & 13 & 10 & 63 & 7 & 0 & 236 \\
Mg-rich coating & 6 & 13 & 66 & 15 & 0 & 0 & 40 \\
Na-rich coating & 0 & 13 & 20 & 27 & 0 & 40 & 30 \\
K-rich coating & 30 & 40 & 10 & 10 & 10 & 0 & 13 \\
S-rich coating & 18 & 36 & 0 & 18 & 18 & 9 & 13 \\
\hline
\end{tabular}

Si-rich (Si, [Ca]): quartz; $\mathrm{Si}-\mathrm{Al}$ (Si, Al, [Ca]): clay, feldspar, and hornblende; $\mathrm{Ca}-\mathrm{Mg}$ (Ca, $\mathrm{Mg},[\mathrm{Si}, \mathrm{Al}])$ : dolomite; Ca-rich (Ca, [Si, $\mathrm{Mg}$, $\mathrm{Al}])$ : calcite; Fe-rich (Fe, [Ca, $\mathrm{Si}, \mathrm{Al}])$ : hematite; Na-rich (Na, [Si, $\mathrm{Al}])$ : halite.

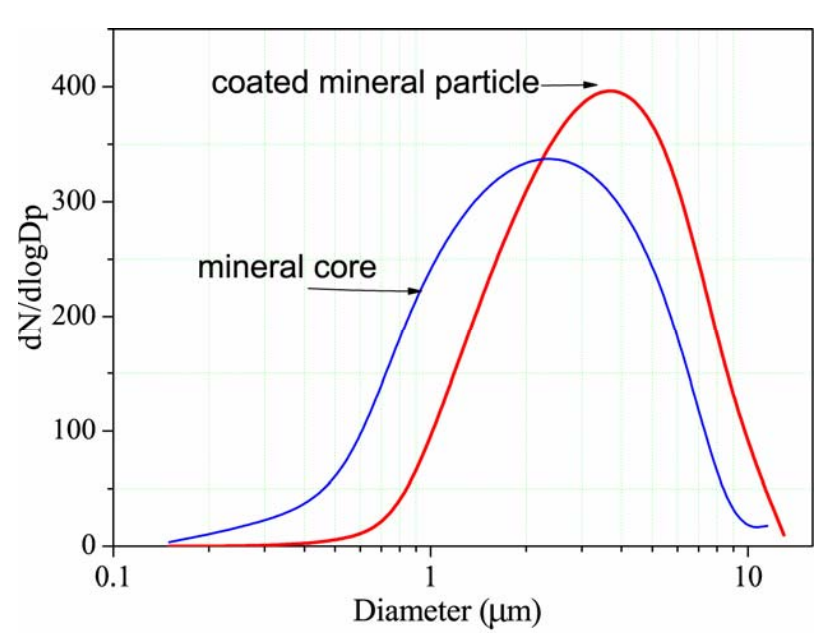

Fig. 3. Size distributions of 332 coated mineral particles and their cores.

332 coated mineral particles range from 0.4 to $16 \mu \mathrm{m}$ with a median diameter of $3.1 \mu \mathrm{m}$ (Fig. 3).

Based on morphological features, we can distinguish two parts of each coated mineral particle: core and coating (Fig. 2). In our samples, the cores are composed of Si-rich (e.g., quartz), Si-Al (e.g., clay, feldspar, and hornblende), Mg-Ca (e.g., dolomite), Ca-rich (e.g., calcite), and Fe-rich (e.g., hematite) (Table 1). One or more mineral components may act as cores that are enclosed within a single coating. Cores have diameters from 0.2 to $13 \mu \mathrm{m}$ with median size $2.1 \mu \mathrm{m}$ (Fig. 3). Most coatings are transparent in TEM images and sensitive to the strong electron beam.

\subsection{Coatings on mineral particles}

A total of 330 coated mineral particles in ten haze samples and two coated mineral particles in one dust sample were investigated using TEM/EDX. EDX analysis shows that coatings mainly include $\mathrm{N}, \mathrm{O}, \mathrm{Na}, \mathrm{Mg}, \mathrm{S}, \mathrm{Cl}, \mathrm{K}$, and $\mathrm{Ca}$. Although some mineral particles were covered with two or more components, one dominant component could be iden-

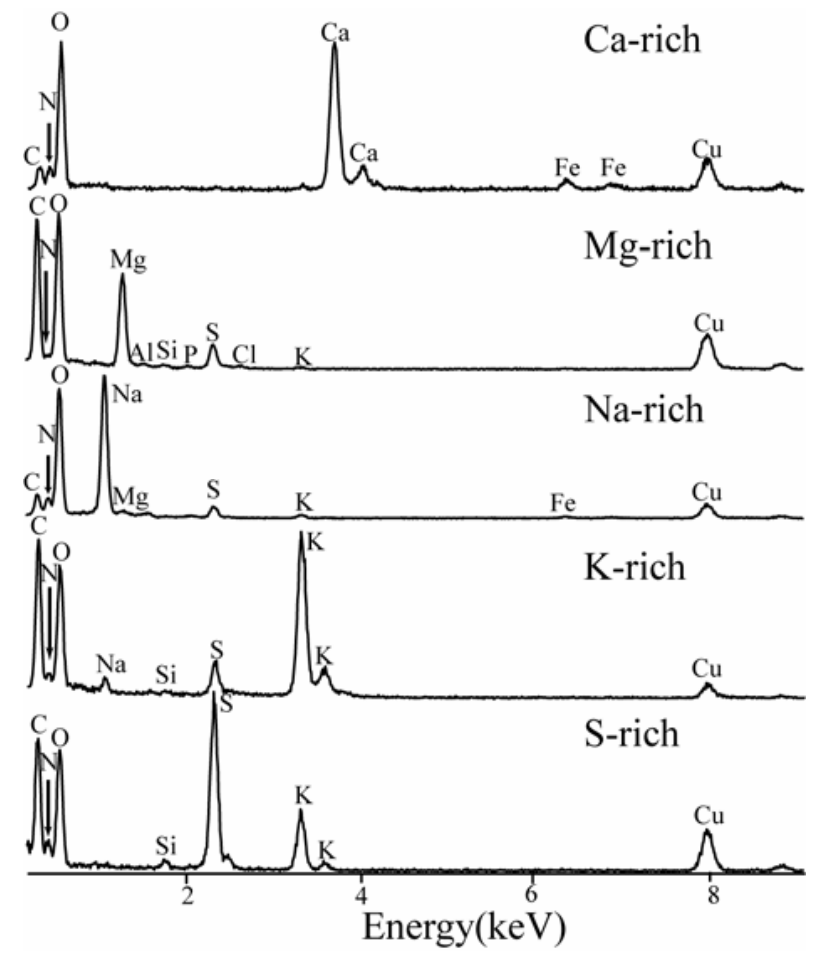

Fig. 4. Typical EDX spectra of Ca-, Mg-, Na-, K-, and S-rich coatings. $\mathrm{C}$ and $\mathrm{Cu}$ in spectra were not considered because of copper TEM grids and carbon film.

tified using EDX spectra. Based on the major compositions, the coatings were classified into five categories (Fig. 4). They include Ca-rich (71\%), Mg-rich (12\%), and Na-rich (9\%) as well as small amounts of K-rich (4\%) and S-rich coatings $(4 \%)$.

Ca-rich coating: Most of mineral particles associated with Ca-rich coatings are mixtures of silicates and calcite (or dolomite) (Table 1 and Fig. 5). EDX analysis shows that Ca-rich coatings also contain $\mathrm{O}$ and $\mathrm{N}$ with minor amounts of $\mathrm{S}, \mathrm{Cl}$, and $\mathrm{Mg}$. $\mathrm{CaSO}_{4}$ particles with the diameter from 10 to $500 \mathrm{~nm}$ were detected in these amorphous coatings 


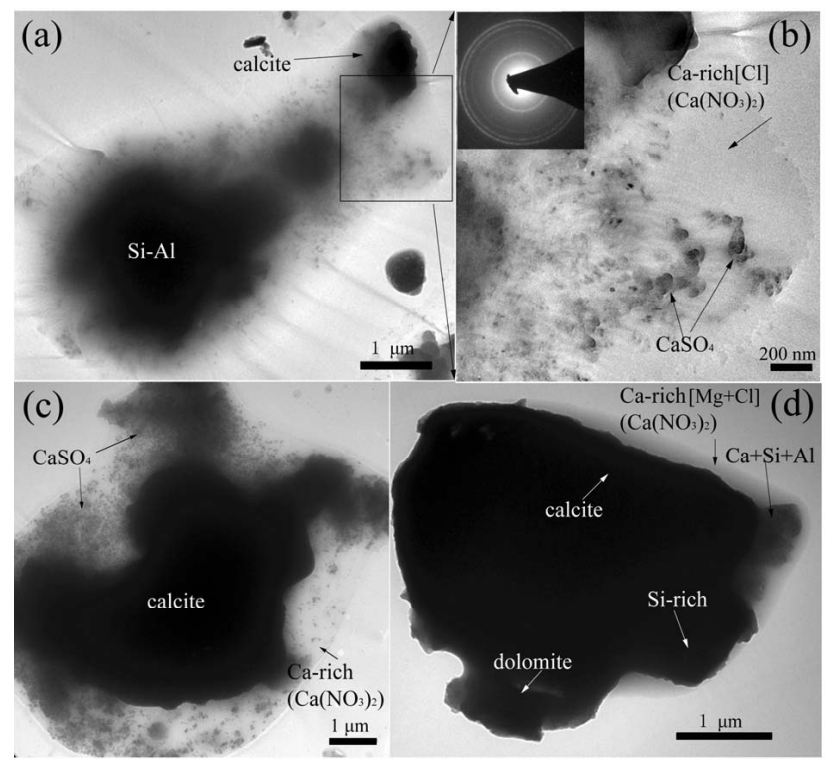

Fig. 5. TEM images of mineral dust particles covered by Ca-rich coatings. Major compositions are shown in parentheses, and minor elements are mentioned in square brackets. (a) A mineral particle that includes different mineral components (aluminosilicate and calcite $\left.\left(\mathrm{CaCO}_{3}\right)\right)$ is covered by Ca-rich coatings. (b) High-resolution TEM image of the partial mineral particle in image (a). Amorphous Ca-rich coatings including the crystal particles with the diameter at $20-50 \mathrm{~nm}$. SAED diffraction indicates that these particles are $\mathrm{CaSO}_{4}$. (c) Calcite particle is covered by Ca-rich coatings with $\mathrm{CaSO}_{4}$ particles. (d) Mineral aggregates with different mineral components are covered partially by Ca-rich coatings.

(Fig. 5b). The ternary diagram of Ca-O-N shows that most Ca-rich coatings are closely distributed around the standard $\mathrm{Ca}\left(\mathrm{NO}_{3}\right)_{2}$ generated in laboratory (Fig. 6). In our study, the oxygen intensities from EDX spectra are also larger in the coatings than in the corresponding cores. The properties of coatings are similar to that of $\mathrm{Ca}\left(\mathrm{NO}_{3}\right)_{2}$ described by Laskin et al. (2005b). Most Ca-rich coatings examined by EDX analysis also include minor chlorine. Murphy et al. (2006) measured chlorides at the surface of most nitrate coatings on dust particles in the troposphere using laser mass spectrometry. Scavenging of $\mathrm{HCl}$ and $\mathrm{HNO}_{3}$ from the gas phase by mineral particles is also thermodynamically favorable (Kelly and Wexler, 2005). Minor $\mathrm{Cl}$ in Ca-rich coatings is inferred from $\mathrm{CaCl}_{2}$ and $\mathrm{MgCl}_{2}$ internally mixed with $\mathrm{Ca}\left(\mathrm{NO}_{3}\right)_{2}$.

Mg-rich coating: Mineral particles associated with $\mathrm{Mg}$ rich coatings are mixtures of silicates and dolomite (Table 1). Mg-rich coatings also contain $\mathrm{N}$ and $\mathrm{O}$ with minor amounts of $\mathrm{Cl}$ and $\mathrm{Ca}$. $\mathrm{CaSO}_{4}$ inclusions are also detected in some coatings (Fig. 7a, b). Mg-rich coatings are amorphous. Although characteristics of Mg-rich components (e.g., $\mathrm{Mg}\left(\mathrm{NO}_{3}\right)_{2}, \mathrm{MgSO}_{4}$, and $\mathrm{MgCl}_{2}$ ) were studied in laboratory experiments (Ha and Chan, 1999; Li et al., 2008), the association of $\mathrm{Mg}$-rich coatings with mineral particles is very

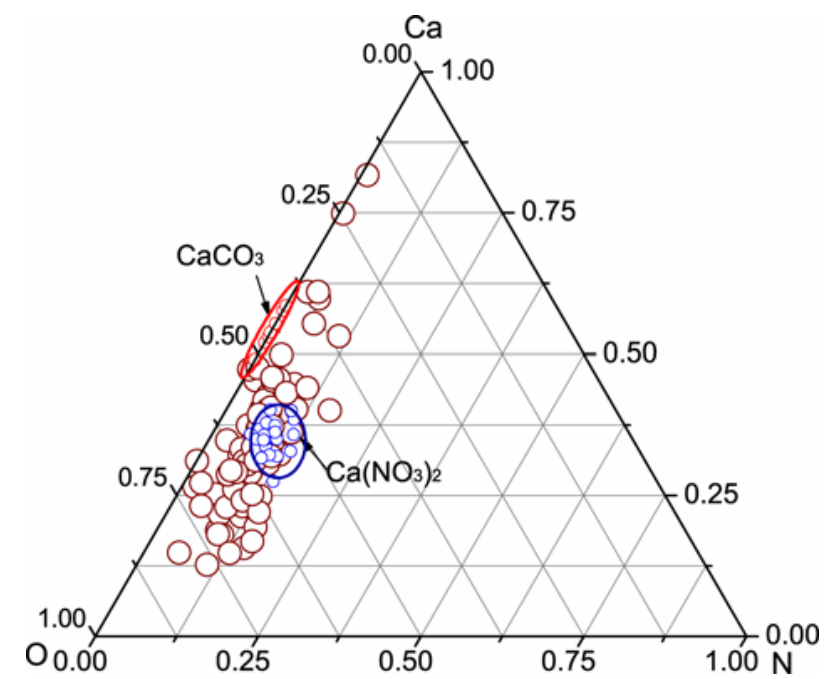

Fig. 6. Ternary diagrams showing EDX data of elemental compositions of Ca-rich coatings of 236 mineral particles. Reference areas represent the elemental compositions of laboratory generated $\mathrm{CaCO}_{3}$ (red ellipse) and $\mathrm{Ca}\left(\mathrm{NO}_{3}\right)_{2}$ (blue ellipse) particles. All the particles were analyzed in the same TEM system with very close conditions.

limited in field studies. We believe that Mg-rich coatings are possibly mixtures of $\mathrm{Mg}\left(\mathrm{NO}_{3}\right)_{2}$ and $\mathrm{Mg}$-bearing sulfates as well as minor chlorides (i.e., $\mathrm{MgCl}_{2}$ and $\mathrm{CaCl}_{2}$ ). In addition, measurements show that most $\mathrm{Mg}$-rich coatings were internally mixed with $\mathrm{Ca}\left(\mathrm{NO}_{3}\right)_{2}$ (Fig. 7f). Similar mixtures were described in a laboratory study of China loess reacted with $\mathrm{HNO}_{3}$ (Laskin et al., 2005b).

Na-rich coating: Some Na-rich coatings yield SAED patterns of $\mathrm{Na}_{2} \mathrm{SO}_{4}$ but the majority of coatings are amorphous (Fig. 7c). EDX analysis shows that Na-rich coatings also consist of $\mathrm{N}, \mathrm{O}$, and $\mathrm{S}$ with minor amounts of $\mathrm{Mg}$ and $\mathrm{Ca}$. Their compositions indicate that they possibly include $\mathrm{NaNO}_{3}$ and $\mathrm{Na}_{2} \mathrm{SO}_{4}$ as well as minor $\mathrm{Ca}\left(\mathrm{NO}_{3}\right)_{2}$ and $\mathrm{Mg}\left(\mathrm{NO}_{3}\right)_{2}$.

$K$ - and S-rich coating: $\mathrm{K}$ - and S-rich coatings usually enclose or coagulate with the submicron mineral particles (Fig. 7d, e). We also found many K- and S-rich particles without mineral particles in our samples. K-rich coatings consist of $\mathrm{N}, \mathrm{O}$, and $\mathrm{S}$, suggesting that they are a mixture of K-bearing sulfates and $\mathrm{KNO}_{3}$ (Fig. 7e). S-rich particles are sensitive to the electron beam, and also consist of $\mathrm{N}$ and $\mathrm{O}$ (Fig. $7 \mathrm{~d})$. The particles are likely $\left(\mathrm{NH}_{4}\right)_{2} \mathrm{SO}_{4}$.

\section{Discussion}

\subsection{Comparisons of coatings on mineral particles}

Numerous studies have shown that nitrate coatings form on atmospheric mineral particles through heterogeneous 


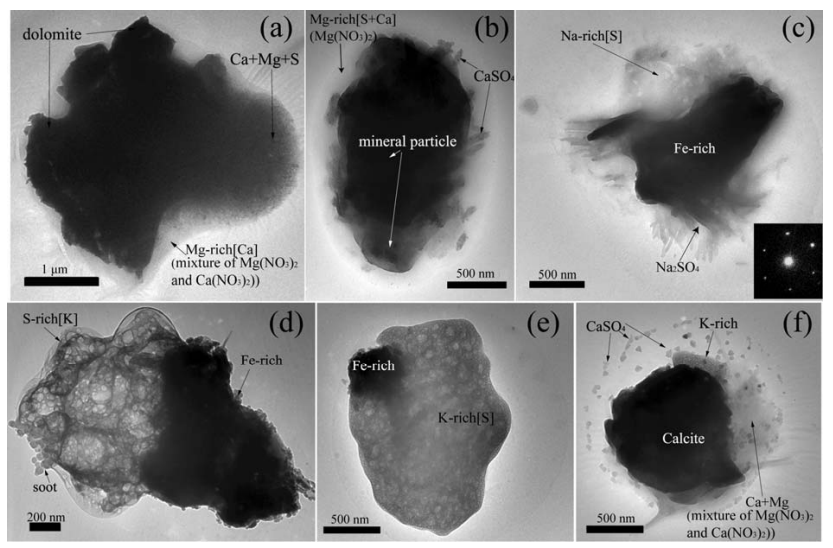

Fig. 7. TEM images of mineral particles with coatings. Major compositions are shown in parentheses, and minor elements are mentioned in square brackets. (a) Dolomite particle $\left(\mathrm{CaMg}\left(\mathrm{CO}_{3}\right)_{2}\right)$ is covered by $\mathrm{Mg}$-rich coatings with $\mathrm{CaSO}_{4}$ and $\mathrm{MgSO}_{4}$ particles. (b) Mineral particle is covered by Mg-rich coatings including $\mathrm{CaSO}_{4}$ particles. (c) Fe-rich mineral particle is coated by $\mathrm{NaNO}_{3}$ and $\mathrm{Na}_{2} \mathrm{SO}_{4}, \mathrm{Na}_{2} \mathrm{SO}_{4}$ was confirmed by SAED. (d) Fe-rich mineral particle coagulate with soot and S-rich particle with minor K. (e) Fe-rich mineral particle coagulate with K-rich particle. (f) Calcite particle is enclosed by a mixed coating which likely includes $\mathrm{K}$-rich, $\mathrm{Ca}\left(\mathrm{NO}_{3}\right)_{2}$, and $\mathrm{Mg}\left(\mathrm{NO}_{3}\right)_{2}$ with $\mathrm{CaSO}_{4}$ particles.

reactions with gaseous nitric acid (Zhang and Iwasaka, 1999; Laskin et al., 2005a; Matsuki et al., 2005; Sullivan et al., 2007). Our results show that abundant nitrate coatings formed on mineral particles during brown haze episodes, whereas few coatings occurred in the dust episode. Higher concentrations of $\mathrm{SO}_{2}$ and $\mathrm{NO}_{2}$ as well as higher $\mathrm{RH}$ shown in Fig. 1 occurred during brown haze episodes than during dust episode. These comparisons indicate that high concentrations of anthropogenic acidic gases and high RH can enhance heterogeneous reactions on mineral dust and form coatings. Consistent with this conclusion, abundant mineral dust particles containing calcite or dolomite without coatings were detected in the dust sample. Our results also show that $\mathrm{Ca}\left(\mathrm{NO}_{3}\right)_{2}$ and $\mathrm{Mg}\left(\mathrm{NO}_{3}\right)_{2}$ coatings preferentially formed on mineral particles which contain calcite and dolomite components (Table 1). This is in agreement with previous studies (Zhang and Iwasaka, 1999; Matsuki et al., 2005; Laskin et al., 2005a; Hwang and Ro, 2006). On the other hand, a small number of K- and S-rich coatings on mineral particles occurred in brown haze episodes (Table 1). Ammonium sulfate and K-rich particles tend to accumulate in submicron clay mineral particles through their coagulations in air (Sullivan et al., 2007).

\subsection{Reactions on mineral particles}

Mineral particles with hygroscopic coatings are more reactive with acidic gases than those without coatings (Usher et al., 2003). In our samples, most nitrate coatings include mi- nor amounts of sulfates and chlorides, likely as a result of heterogeneous reactions. The reactions of alkaline mineral dust with $\mathrm{HNO}_{3}$ are several orders of magnitude faster than with $\mathrm{HCl}, \mathrm{NO}_{2}$, or $\mathrm{SO}_{2}$ (Ullerstam et al., 2003; Ooki and Uematsu, 2005; Vlasenko et al., 2006). The polluted air of Beijing contains abundant $\mathrm{HNO}_{3}, \mathrm{SO}_{2}$, and $\mathrm{NO}_{2}$ (Bergin et al., 2001), alkaline mineral particles may first react with $\mathrm{HNO}_{3}$ and form nitrate coatings on mineral particles. The hydrophilic nitrate coatings significantly enhance the uptake capacity of water and some gases (e.g., $\mathrm{NO}_{\mathrm{x}}, \mathrm{SO}_{2}, \mathrm{HCl}$, and $\mathrm{O}_{3}$ ) on mineral particles in the atmosphere (Usher et al., 2003; Fountoukis and Nenes, 2007).

Our study clearly shows that $\mathrm{CaSO}_{4}$ particles occurred in $\mathrm{Ca}\left(\mathrm{NO}_{3}\right)_{2}$ and $\mathrm{Mg}\left(\mathrm{NO}_{3}\right)_{2}$ coatings, although $\mathrm{CaSO}_{4}$ associated with $\mathrm{Ca}\left(\mathrm{NO}_{3}\right)_{2}$ was previously detected by Zhang et al. (2000) and Hwang and Ro (2006). Pandis and Seinfeld (1989) showed that conversion of S (IV) to S (VI) in the atmosphere occurs during aqueous chemistry through the oxidation of $\mathrm{S}(\mathrm{IV})$ by $\mathrm{H}_{2} \mathrm{O}_{2}, \mathrm{O}_{3}$, and/or $\mathrm{O}_{2}$ (catalyzed by $\mathrm{Fe}^{3+}$ and $\mathrm{Mn}^{2+}$ ). The presence of $\mathrm{CaSO}_{4}$ particles in coatings is likely to be the result of $\mathrm{SO}_{2}$ absorbed on aqueous nitrate coatings and then converted into $\mathrm{CaSO}_{4}$ particles through aqueous chemical reactions. $\mathrm{CaSO}_{4}$ and nitrate coatings together forming on mineral dust particles are consistent with previous laboratory simulation that calcite can react with $\mathrm{SO}_{2}$ and $\mathrm{HNO}_{3}$ to form sulfate crystalline particles and nitrate deliquescent layer (Al-Hosney and Grassian, 2005).

\subsection{Atmospheric implications}

Mineral dust particles with nitrate coatings are hydrophilic, and those without coating are commonly hydrophobic (Kelly et al., 2007; Shi et al., 2008). The deliquescence relative humidities (DRHs) of hydrated $\mathrm{Ca}\left(\mathrm{NO}_{3}\right)_{2}$ and $\mathrm{Mg}\left(\mathrm{NO}_{3}\right)_{2}$ are $\sim 12 \%$ and $\sim 11 \%$, respectively (Tang and Fung, 1997; Li et al., 2008). The DRHs are lower than the RH measured in every brown haze day. The results indicate that mineral dust particles with the nitrate coatings should be larger and more spherical during the polluted days of high $\mathrm{RH}$. The coated mineral particles can act as $\mathrm{CCN}$ and enhance scattering when they are entrained and transported in the troposphere (Gibson et al., 2006a; Kelly et al., 2007). In the global scale, the coating processes can change the distributions of sulfate, nitrate, and mineral particle in atmosphere, and therefore change their impact on earth radiation (Bauer et al., 2007).

$\mathrm{HNO}_{3}$ in the atmosphere is taken up by mineral dust particles as nitrates, reducing photochemically active $\mathrm{NO}_{\mathrm{x}}$ (Hanisch and Crowley, 2001; Underwood et al., 2001; Liao et al., 2003; Gibson et al., 2006b). As a result, mineral dust particles in northern China can affect photochemical oxidation in the regional atmosphere. 


\section{Conclusions}

TEM analysis provides detailed information regarding the coated mineral particles collected during brown haze and dust episodes between 24 May and 21 June 2007 in Beijing, northern China. TEM observations of mineral particles show that about $90 \%$ of mineral particles have coatings in the haze samples and 5\% in the dust sample. Mineral particles are mainly covered with coating including $\mathrm{Ca}\left(\mathrm{NO}_{3}\right)_{2}, \mathrm{Mg}\left(\mathrm{NO}_{3}\right)_{2}$, and $\mathrm{NaNO}_{3}$. High concentrations of $\mathrm{NO}_{2}$ and high humidity during the brown haze days can enhance heterogeneous reactions on alkaline mineral dust and form nitrate coatings. These coatings enhance both the size and hygroscopic properties of mineral particles. These large particles will contribute to cooling in the study region. $\mathrm{Ca}$ - and $\mathrm{Mg}$-rich coatings also contained minor sulfates and chlorides. Many $\mathrm{CaSO}_{4}$ particles with diameters from 10 to $500 \mathrm{~nm}$ are enclosed within these coatings. These tiny $\mathrm{CaSO}_{4}$ particles likely formed in aqueous nitrate coatings in polluted air. The results show that mineral particles including alkaline components can be involved in atmospheric heterogeneous reactions with two or more acidic gases.

Acknowledgements. We thank Wei Wang for assistance with sample collection. We are grateful to Peter Buseck, Kouji Adachi, and Evelyn Freney for their discussions of this manuscript and to Buseck for sponsoring the visit of WJL to Arizona State University. We acknowledge use of TEM in the LeRoy Eyring Center for Solid State Science at Arizona State University. Financial support was provided by National Basic Research Program of China (No. 2006CB403701), National Natural Science Foundation of China (No. 40575065), and Cultivation Fund of the Key Scientific and Technical Innovation Project of the Ministry of Education of China (No. 705022). We gratefully acknowledge the NOAA Air Resources Laboratory (ARL) for the provision of the HYSPLIT transport used in this publication.

Edited by: M. Ammann

\section{References}

Al-Hosney, H. A. and Grassian, V. H.: Water, sulfur dioxide and nitric acid adsorption on calcium carbonate: A transmission and ATR-FTIR study, Phys. Chem. Chem. Phys., 7, 1266-1276, 2005.

Andreae, M. O.: Climatic effects of changing atmospheric aerosol levels, in Future Climates of the World: A Modeling Perspective, World Survey of Climatology, edited by: Henderson, A., Elsevier, New York, 1620-1623, 1995.

Bauer, S. E., Mishchenko, M. I., Lacis, A. A., Zhang, S., Perlwitz, J., and Metzger, S. M.: Do sulfate and nitrate coatings on mineral dust have important effects on radiative properties and climate modeling?, J. Geophys. Res.-Atmos., 112, D06307, doi:10.1029/2005jd006977, 2007.

Bergin, M. H., Cass, G. R., Xu, J., Fang, C., Zeng, L. M., Yu, T., Salmon, L. G., Kiang, C. S., Tang, X. Y., Zhang, Y. H., and Chameides, W. L.: Aerosol radiative, physical, and chemical properties in Beijing during June 1999, J. Geophys. Res.-Atmos., 106, 17969-17980, 2001.

Borensen, C., Kirchner, U., Scheer, V., Vogt, R., and Zellner, R.: Mechanism and kinetics of the reactions of $\mathrm{NO}_{2}$ or $\mathrm{HNO}_{3}$ with alumina as a mineral dust model compound, J. Phys. Chem. A, 104, 5036-5045, 2000.

Buseck, P. R. and Posfai, M.: Airborne minerals and related aerosol particles: Effects on climate and the environment, P. Natl. Acad. Sci. USA, 96, 3372-3379, 1999.

Buseck, P. R., Jacob, D. J., Posfai, M., Li, J., and Anderson, J. R.: Minerals in the air: An environmental perspective, Int. Geol. Rev., 42, 577-593, 2000.

Chan, C. K. and Yao, X.: Air pollution in mega cities in China, Atmos. Environ., 42, 1-42, 2008.

Dentener, F. J., Carmichael, G. R., Zhang, Y., Lelieveld, J., and Crutzen, P. J.: Role of mineral aerosol as a reactive surface in the global troposphere, J. Geophys. Res.-Atmos., 101, 22869 22889, 1996.

Draxler, R. R. and Rolph, G. D.: (HYbrid Single-Particle Lagrange Integrated Trajectory) Model access via NOAA ARL READY Website (http://www.arl.noaa.gov/ready/hysplit4.html), NOAA Air Resources Laboratory, Silver Spring, MD., 2003.

Fairlie, T. D., Jacob, D. J., and Park, R. J.: The impact of transpacific transport of mineral dust in the United States, Atmos. Environ., 41, 1251-1266, 2007.

Fountoukis, C. and Nenes, A.: ISORROPIA II: a computationally efficient thermodynamic equilibrium model for $\mathrm{K}^{+}$. $\mathrm{Ca}^{2+}-\mathrm{Mg}^{2+}-\mathrm{NH}_{4}^{+}-\mathrm{Na}^{+}-\mathrm{SO}_{4}^{2-}-\mathrm{NO}_{3}^{-}-\mathrm{Cl}^{-}-\mathrm{H}_{2} \mathrm{O}$ aerosols, Atmos. Chem. Phys., 7, 4639-4659, 2007, http://www.atmos-chem-phys.net/7/4639/2007/.

Gibson, E. R., Hudson, P. K., and Grassian, V. H.: Aerosol chemistry and climate: Laboratory studies of the carbonate component of mineral dust and its reaction products, Geophys. Res. Lett., 33, L13811, doi:10.1029/2006GL026386, 2006a.

Gibson, E. R., Hudson, P. K., and Grassian, V. H.: Physicochemical properties of nitrate aerosols: Implications for the atmosphere, J. Phys. Chem. A, 110, 11785-11799, 2006b.

Guinot, B., Cachier, H., Sciare, J., Tong, Y., Xin, W., and Jianhua, Y.: Beijing aerosol: Atmospheric interactions and new trends, J. Geophys. Res.-Atmos., 112, 16, D14314, doi:10.1029/2006JD008195, 2007.

Ha, Z. Y. and Chan, C. K.: The water activities of $\mathrm{MgCl}_{2}$, $\mathrm{Mg}\left(\mathrm{NO}_{3}\right)_{2}, \mathrm{MgSO}_{4}$, and their mixtures, Aerosol Sci. Tech., 31, 154-169, 1999.

Hanisch, F. and Crowley, J. N.: Heterogeneous reactivity of gaseous nitric acid on $\mathrm{Al}_{2} \mathrm{O}_{3}, \mathrm{CaCO}_{3}$, and atmospheric dust samples: A Knudsen cell study, J. Phys. Chem. A., 105, 3096-3106, doi:10.1021/jp001254, 2001.

Haywood, J. and Boucher, O.: Estimates of the direct and indirect radiative forcing due to tropospheric aerosols: A review, Rev. Geophys., 38, 513-543, 2000.

Husar, R. B., Tratt, D. M., Schichtel, B. A., Falke, S. R., Li, F., Jaffe, D., Gasso, S., Gill, T., Laulainen, N. S., Lu, F., Reheis, M. C., Chun, Y., Westphal, D., Holben, B. N., Gueymard, C., McKendry, I., Kuring, N., Feldman, G. C., McClain, C., Frouin, R. J., Merrill, J., DuBois, D., Vignola, F., Murayama, T., Nickovic, S., Wilson, W. E., Sassen, K., Sugimoto, N., and Malm, W. C.: Asian dust events of April 1998, J. Geophys. Res.-Atmos., 106, 18317-18330, 2001. 
Hwang, H. J. and Ro, C. U.: Direct observation of nitrate and sulfate formations from mineral dust and sea-salts using low- $\mathrm{Z}$ particle electron probe X-ray microanalysis, Atmos. Environ., 40, 38693880, 2006.

Jacob, D. J.: Heterogeneous chemistry and tropospheric ozone, Atmos. Environ., 34, 2131-2159, 2000.

Johnson, K. S., Zuberi, B., Molina, L. T., Molina, M. J., Iedema, M. J., Cowin, J. P., Gaspar, D. J., Wang, C., and Laskin, A.: Processing of soot in an urban environment: case study from the Mexico City Metropolitan Area, Atmos. Chem. Phys., 5, 30333043, 2005,

http://www.atmos-chem-phys.net/5/3033/2005/.

Kelly, J. T. and Wexler, A. S.: Thermodynamics of carbonates and hydrates related to heterogeneous reactions involving mineral aerosol, J. Geophys. Res.-Atmos., 110, D11201, doi:10.1029/2004JD005583, 2005.

Kelly, J. T., Chuang, C. C., and Anthony, S. W.: Influence of dust composition on cloud droplet formation, Atmos. Environ., 41, 2904-2904, 2007.

Kojima, T., Buseck, P. R., Iwasaka, Y., Matsuki, A., and Trochkine, D.: Sulfate-coated dust particles in the free troposphere over Japan, Atmos. Res., 82, 698-708, 2006.

Kojima, T., Buseck, P. R., and Reeves, J. M.: Aerosol particles from tropical convective systems: 2. Cloud bases, J. Geophys. Res.Atmos., 110, 9203-9203, 2005.

Krueger, B. J., Grassian, V. H., Cowin, J. P., and Laskin, A.: Heterogeneous chemistry of individual mineral dust particles from different dust source regions: the importance of particle mineralogy, Atmos. Environ., 38, 6253-6261, doi:10.1016/j.atmosenv.2004.07.010, 2004.

Krueger, B. J., Grassian, V. H., Laskin, A., and Cowin, J. P.: The transformation of solid atmospheric particles into liquid droplets through heterogeneous chemistry: Laboratory insights into the processing of calcium containing mineral dust aerosol in the troposphere, Geophys. Res. Lett., 30(3), 1148, doi:10.1029/2002g1016563, 2003.

Laskin, A., Iedema, M. J., Ichkovich, A., Graber, E. R., Taraniuk, I., and Rudich, Y.: Direct observation of completely processed calcium carbonate dust particles, Faraday Discuss., 130, 453468, doi:10.1039/b417366j, 2005a.

Laskin, A., Wietsma, T. W., Krueger, B. J., and Grassian, V. H.: Heterogeneous chemistry of individual mineral dust particles with nitric acid: A combined CCSEM/EDX, ESEM, and ICP-MS study, J. Geophys. Res.-Atmos., 110, D10208, doi:10.1029/2004jd005206, 2005b.

Levin, Z., Ganor, E., and Gladstein, V.: The effects of desert particles coated with sulfate on rain formation in the eastern Mediterranean, J. Appl. Meteor., 35, 1511-1523, 1996.

Li, X. H., Zhao, L. J., Dong, J. L., Xiao, H. S., and Zhang, Y. H.: Confocal Raman studies of $\mathrm{Mg}\left(\mathrm{NO}_{3}\right)_{2}$ aerosol particles deposited on a quartz substrate: Supersaturated structures and complicated phase transitions, J. Phys. Chem. B, 112, 5032-5038, doi:10.1021/jp709938x, 2008.

Li, Z. Q., Chen, H., Cribb, M., Dickerson, R., Holben, B., Li, C., Lu, D., Luo, Y., Maring, H., Shi, G., Tsay, S. C., Wang, P., Wang, Y., Xia, X., Zheng, Y., Yuan, T., and Zhao, F.: Preface to special section on east Asian studies of tropospheric aerosols: An international regional experiment (EAST-AIRE), J. Geophys. Res.Atmos., 112, D22S00, doi:10.1029/2007JD008853, 2007.
Liao, H., Adams, P. J., Chung, S. H., Seinfeld, J. H., Mickley, L. J., and Jacob, D. J.: Interactions between tropospheric chemistry and aerosols in a unified general circulation model, J. Geophys. Res.-Atmos., 108, 4001, doi:10.1029/2001jd001260, 2003.

Matsuki, A., Iwasaka, Y., Shi, G. Y., Zhang, D. Z., Trochkine, D., Yamada, M., Kim, Y. S., Chen, B., Nagatani, T., Miyazawa, T., Nagatani, M., and Nakata, H.: Morphological and chemical modification of mineral dust: Observational insight into the heterogeneous uptake of acidic gases, Geophys. Res. Lett., 32, L22806, doi:10.1029/2005GL024176, 2005.

Middlebrook, A. M., Murphy, D. M., Lee, S. H., Thomson, D. S., Prather, K. A., Wenzel, R. J., Liu, D. Y., Phares, D. J., Rhoads, K. P., Wexler, A. S., Johnston, M. V., Jimenez, J. L., Jayne, J. T., Worsnop, D. R., Yourshaw, I., Seinfeld, J. H., and Flagan, R. C.: A comparison of particle mass spectrometers during the 1999 Atlanta Supersite Project, J. Geophys. Res.-Atmos., 108(D7), 8424, doi:10.1029/2001JD000660, 2003.

Murphy, D. M., Cziczo, D. J., Froyd, K. D., Hudson, P. K., Matthew, B. M., Middlebrook, A. M., Peltier, R. E., Sullivan, A., Thomson, D. S., and Weber, R. J.: Single-particle mass spectrometry of tropospheric aerosol particles, J. Geophys. Res.-Atmos., 111, D23S32, doi:10.1029/2006jd007340, 2006.

Niemi, J. V., Saarikoski, S., Tervahattu, H., Makela, T., Hillamo, R., Vehkamaki, H., Sogacheva, L., and Kulmala, M.: Changes in background aerosol composition in Finland during polluted and clean periods studied by TEM/EDX individual particle analysis, Atmos. Chem. Phys., 6, 5049-5066, 2006, http://www.atmos-chem-phys.net/6/5049/2006/.

Okada, K. and Hitzenberger, R. M.: Mixing properties of individual submicrometer aerosol particles in Vienna, Atmos. Environ., 35, 5617-5628, 2001.

Ooki, A. and Uematsu, M.: Chemical interactions between mineral dust particles and acid gases during Asian dust events, J. Geophys. Res.-Atmos., 110, 3201-3201, 2005.

Pandis, S. N. and Seinfeld, J. H.: Sensitivity analysis of a chemical mechanism for aqueous-phase atmospheric chemistry, J. Geophys. Res.-Atmos., 94, 1105-1126, 1989.

Posfai, M., Anderson, J. R., Buseck, P. R., and Sievering, H.: Compostioinal variations of sea-salt-mode aerosol-particles from the North-Atlantic, J. Geophys. Res.-Atmos., 100, 23063-23074, 1995.

Ravishankara, A. R.: Heterogeneous and multiphase chemistry in the troposphere, Science, 276, 1058-1065, 1997.

Seinfeld, J. H., Carmichael, G. R., Arimoto, R., Conant, W. C., Brechtel, F. J., Bates, T. S., Cahill, T. A., Clarke, A. D., Doherty, S. J., Flatau, P. J., Huebert, B. J., Kim, J., Markowicz, K. M., Quinn, P. K., Russell, L. M., Russell, P. B., Shimizu, A., Shinozuka, Y., Song, C. H., Tang, Y. H., Uno, I., Vogelmann, A. M., Weber, R. J., Woo, J. H., and Zhang, X. Y.: ACE-ASIA - Regional climatic and atmospheric chemical effects of Asian dust and pollution, B. Am. Meteorol. Soc., 85, 367-380, 2004.

Shi, Z., Zhang, D., Hayashi, M., Ogata, H., Ji, H., and Fujiie, W.: Influences of sulfate and nitrate on the hygroscopic behaviour of coarse dust particles, Atmos. Environ., 42, 822-827, 2008.

Shao, L. Y., Li, W. J., Xiao, Z. H., and Sun, Z. Q.: The mineralogy and possible sources of spring dust particles over Beijing, Adv. Atmos. Sci., 25, 395-403, doi:10.1007/s00376-008-03958, 2008.

Sokolik, I. N. and Toon, O. B.: Direct radiative forcing by anthro- 
pogenic airborne mineral aerosols, Nature, 381, 681-683, 1996.

Streets, D. G., Bond, T. C., Carmichael, G. R., Fernandes, S. D., Fu, Q., He, D., Klimont, Z., Nelson, S. M., Tsai, N. Y., Wang, M. Q., Woo, J. H., and Yarber, K. F.: An inventory of gaseous and primary aerosol emissions in Asia in the year 2000, J. Geophys. Res.-Atmos., 108(D21), 8809, doi:10.1029/2002JD003093, 2003.

Sullivan, R. C., Guazzotti, S. A., Sodeman, D. A., and Prather, K. A.: Direct observations of the atmospheric processing of Asian mineral dust, Atmos. Chem. Phys., 7, 1213-1236, 2007, http://www.atmos-chem-phys.net/7/1213/2007/.

Sun, Y. L., Zhuang, G. S., Tang, A. H., Wang, Y., and An, Z. S.: Chemical characteristics of $\mathrm{PM}_{2.5}$ and $\mathrm{PM}_{10}$ in haze-fog episodes in Beijing, Environ. Sci. Technol., 40, 3148-3155, 2006.

Tang, I. N. and Fung, K. H.: Hydration and Raman scattering studies of levitated microparticles: $\mathrm{Ba}\left(\mathrm{NO}_{3}\right)_{2}, \mathrm{Sr}\left(\mathrm{NO}_{3}\right)_{2}$, and $\mathrm{Ca}\left(\mathrm{NO}_{3}\right)_{2}$, J. Phys. Chem., 106, 1653-1660, 1997.

Tegen, I., Koch, D., Lacis, A. A., and Sato, M.: Trends in tropospheric aerosol loads and corresponding impact on direct radiative forcing between 1950 and 1990: A model study, J. Geophys. Res.-Atmos., 105, 26971-26989, 2000.

Ullerstam, M., Johnson, M. S., Vogt, R., and Ljungstrom, E.: DRIFTS and Knudsen cell study of the heterogeneous reactivity of $\mathrm{SO}_{2}$ and $\mathrm{NO}_{2}$ on mineral dust, Atmos. Chem. Phys., 3, 2043-2051, 2003, http://www.atmos-chem-phys.net/3/2043/2003/.

Underwood, G. M., Song, C. H., Phadnis, M., Carmichael, G. R., and Grassian, V. H.: Heterogeneous reactions of $\mathrm{NO}_{2}$ and $\mathrm{HNO}_{3}$ on oxides and mineral dust: A combined laboratory and modeling study, J. Geophys. Res.-Atmos., 106, 18055-18066, 2001.

Usher, C. R., Michel, A. E., and Grassian, V. H.: Reactions on mineral dust, Chem. Rev., 103, 4883-4939, 2003.
Vlasenko, A., Sjogren, S., Weingartner, E., Stemmler, K., Gaggeler, H. W., and Ammann, M.: Effect of humidity on nitric acid uptake to mineral dust aerosol particles, Atmos. Chem. Phys., 6, $2147-$ 2160, 2006, http://www.atmos-chem-phys.net/6/2147/2006/.

Wang, Y., Zhuang, G. S., Sun, Y. L., and An, Z. S.: The variation of characteristics and formation mechanisms of aerosols in dust, haze, and clear days in Beijing, Atmos. Environ., 40, 6579-6591, 2006.

Xu, J., Bergin, M. H., Greenwald, R., Schauer, J. J., Shafer, M. M., Jaffrezo, J. L., and Aymoz, G.: Aerosol chemical, physical, and radiative characteristics near a desert source region of northwest China during ACE-Asia, J. Geophys. Res.-Atmos., 109, D19S03, doi:10.1029/2003JD004239, 2004.

Yin, Y., Wurzler, S., Levin, Z., and Reisin, T. G.: Interactions of mineral dust particles and clouds: Effects on precipitation and cloud optical properties, J. Geophys. Res.-Atmos., 107(D23), 4724, doi:10.1029/2001jd001544, 2002.

Zhang, D. Z. and Iwasaka, Y.: Nitrate and sulfate in individual Asian dust-storm particles in Beijing, China in spring of 1995 and 1996, Atmos. Environ., 33, 3213-3223, 1999.

Zhang, D. Z., Shi, G. Y., Iwasaka, Y., and Hu, M.: Mixture of sulfate and nitrate in coastal atmospheric aerosols: individual particle studies in Qingdao (36 degrees 04 $4^{\prime}$ N, 120 degrees $21^{\prime}$ E), China, Atmos. Environ., 34, 2669-2679, 2000.

Zhang, Q., Streets, D. G., He, K., Wang, Y., Richter, A., Burrows, J. P., Uno, I., Jang, C. J., Chen, D., Yao, Z., and Lei, Y.: $\mathrm{NO}_{\mathrm{x}}$ emission trends for China, 1995-2004: The view from the ground and the view from space, J. Geophys. Res.-Atmos., 112, D22306, doi: 10.1029/2007jd008684, 2007.

Zhang, X. Y., Gong, S. L., Shen, Z. X., Mei, F. M., Xi, X. X., Liu, L. C., Zhou, Z. J., Wang, D., Wang, Y. Q., and Cheng, Y.: Characterization of soil dust aerosol in China and its transport and distribution during 2001 ACE-Asia: 1. Network observations, J. Geophys. Res.-Atmos., 108(D9), 4261, doi:10.1029/2002JD002632, 2003. 